\title{
Synthesis and Characterization of Some New Azetidin-2-ones Containing Coumarin Moiety and Their Antimicrobial Study
}

\author{
Divyesh Patel (Corresponding author) \\ S.V. National institute of technology, applied chemistry department \\ Surat-395007, India \\ E-mail: dkpatel11984@gmail.com
}

Niketan Patel

S.V. National institute of technology, applied chemistry department

Surat-395007, India

E-mail: niketan.ptl@gmail.com

Premlata Kumari

S.V. National institute of technology, applied chemistry department

Surat-395007, India

Navin Patel

V. N. South Gujarat University, Department of chemistry

Surat-395007, India

Received: September 30, 2010 Accepted: October 19, 2010 doi:10.5539/ijc.v3n2p117

\begin{abstract}
A series of novel azetidinones 5a-i have been synthesized by cyclocondensation of various Schiff bases of coumarin with chloro acetyl chloride in presence of triethyl amine. The reaction of 4-hydroxy coumarin with $\mathrm{POCl}_{3}$ yielded 4-chloro coumarin 2 and 4-chloro-3, 4', 3', 4"-tercoumarin 2a. Compound 2 was reacted with $p$-phenylene diamine to yield 4-[(4-aminophenyl)amino]-2H-chromen-2-one. Various Schiff bases of coumarin were synthesized by condensation of 4-[(4-aminophenyl)amino]-2H- chromen-2-one with different aldehydes. The structures of the newly synthesized compound were confirmed by IR, ${ }^{1} \mathrm{H}$ NMR, ${ }^{13} \mathrm{C}$ NMR and $\mathrm{C}, \mathrm{H}, \mathrm{N}$ analysis. The Schiff bases and azetidnie-2-one derivatives were evaluated for their anti bacterial and antifungal activity by broth dilution method.
\end{abstract}

Keywords: Coumarin, Schiff bases, Azetidinones, Antibacterial, Antifungal

\section{Introduction}

2-Azetidines have been extensively investigated by the organic chemists due to their close association with various types of biological activities (Sharma, M.C. et. al 2009). Azetidine-2-ones also have great importance because of the use of $\beta$-lactam derivatives as antibacterial agents (Toraskar, M. et. al 2010). Recently, some other types of biological activity beside the antibacterial activity have been reported in compounds containing 2-azetidinone ring. Such biological activities include antimicrobial, anti tubercular, anti inflammatory, anticonvulsant, local anesthetics, and hypoglycemic agents (Kumar, V. et. al 2009, Rajasekaran, A. et. al 2010).

Coumarin and its derivatives represent one of the most active classes of compound possessing a wide spectrum of biological activity (Zuo, H. et.al 2008, Lee, S. et.al 2006, Moghadam, K. et.al 2004). Novobiocin and chlorobiocin are established antimicrobials containing a coumarin skeleton (Deklc, S.V. et.al 2007). Many of these compounds found to be active as, antibacterial (El-Saghier, A.M. et.al 2000, Musicki, B. et.al 2000, Azizian, J. et.al 2008), antifungal (Satyanarayan, V.S. et.al 2008), anti inflammatory (Garazd, M.M. et.al 2007), 
anticoagulant (Smitha, G. et.al 2004), anti-HIV (Kotali, A. et.al 2008), and antitumor (Hamdi, N. et.al 2006), In addition, these compounds are used as additives to food and cosmetics (Maheswara, M. et.al 2006). Coumarin derivatives are commonly used as optical whiteners, luminescence dyes (Rajitha, B. et.al 2006), active media for lasers (Zabradnik, M. et.al 1992) and solar collector (Sizova, Z.A. et.al 2002). Various analogues of 4-substituted coumarin such as 4-chlorocoumarins exhibit antimicrobial activity. From the above line of reasoning we directed our work towards synthesis of various coumarin derivatives of biological interest using 4-chloro coumarin as a key starting material.

The aim of the present work was to synthesize new azetidine-2-one derivatives containing coumarin moiety in order to find new biologically active compound. Thus, synthesis of novel azetidine-2-one derivatives has been achieved.

\section{Experimental}

All the chemicals used in the synthesis were of analytical grade. The melting points were determined in open capillary on Veego (Model: VMP-D) electronic apparatus and are uncorrected. The IR spectra of synthesized compounds were recorded on Shimadzu 8400-S FT-IR spectrophotometer using potassium bromide. To monitor the reactions, as well as, to establish the identity and purity of reactants and products, thin layer chromatography was performed on microscopic glass slides $(2 \times 7.5 \mathrm{~cm})$ coated with silica gel-G, using toluene-acetone and chloroform-methanol, as the solvent systems and spots were visualized under UV radiation. Nuclear magnetic resonance spectra were recorded on Varian $400 \mathrm{MHz}$ model spectrometer using DMSO as a solvent and TMS as internal reference (Chemical shifts in $\delta$ ppm). All new compounds were analyzed for $\mathrm{C}, \mathrm{H}$, and $\mathrm{N}$ and the results are in acceptable range.

2.1 Material: 4-Hydroxy coumarin, triethyl amine (TEA), $\mathrm{POCl}_{3}$, $p$-phenylene diamine, aldehydes, chloro acetyl chloride.

\subsection{Synthesis of 4- chloro coumarin (2)}

4-Hydroxycoumarin $1(30 \mathrm{~g}, 0.185 \mathrm{~mol})$ and $60 \mathrm{~mL} \mathrm{POCl}_{3}$ were refluxed for $1 \mathrm{~h}$, cooled, and slowly poured into crushed ice (700 g) with vigorous stirring. The solid was collected by filtration and washed successively with ice-water. Azeotropic distillation with n-hexane, hot filtration of the by-product (15 g, $17 \%$ ), followed by evaporation of solvent and crystallization yielded (21.9 g, 65\%) of 4-chloro coumarin with m.p. 87-89 ${ }^{\circ} \mathrm{C}$ (Kováč, M. et.al 2001); IR (KBr, $\left.\mathrm{cm}^{-1}\right) 1664.62\left(\mathrm{C}=\mathrm{O}\right.$ of coumarin), 773.48(Ar-C-Cl); ${ }^{1} \mathrm{H}-\mathrm{NMR}(400 \mathrm{MHz}$, DMSO- $\left.d_{6}\right) \delta 7.30-7.91(\mathrm{~m}, 3 \mathrm{H}, \mathrm{Ar}-\mathrm{H}), 7.93(\mathrm{~d}, 1 \mathrm{H}, \mathrm{H}$ at C-5 of coumarin), 5.75 (s, $1 \mathrm{H}, \mathrm{H}$ at C-3 of coumarin); ${ }^{13} \mathrm{C}$ NMR 117.22, 118.14, 124.87, 125.84, 130.18, 146.04, 149.04, 149.22, 161.23. Anal. Calcd. For $\mathrm{C}_{9} \mathrm{H}_{5} \mathrm{ClO}_{2}: \mathrm{C}$, 59.86; H, 2.79. Found C, 59. 88; H, 2. 76.

4-chloro-3, 4', 3', 4"-tercoumarin (by-product) (2a): crystallization from acetic acid gave yellowish crystals, m.p. 322-327 ${ }^{\circ} \mathrm{C}$. IR $\left(\mathrm{KBr}, \mathrm{cm}^{-1}\right)$ 769.62(C-Cl), $1718(\mathrm{C}=\mathrm{O}), 1593-1625$ (Aromatic -CH str.), 3039-3080 $(\mathrm{C}=\mathrm{C}), 1187$ (C-O str.); ${ }^{1} \mathrm{H}-\mathrm{NMR}\left(400 \mathrm{MHz}, \mathrm{DMSO}-d_{6}\right) \delta$ 7.46-7.92 (m, 9H, Ar-H), 7.27 (s, 1H, 3'-H); ${ }^{13} \mathrm{C}$ NMR 114.56, $117.60,118.01,118.30,118.83,118.96,120.05,123.40,124.83,125.55,126.00,126.10,126.52,126.69,132.59$, 133.32, 136.13, 149.96, 151.12, 151.95, 156.75, 157.00, 161.80, 163.25. Anal. Calcd. For $\mathrm{C}_{27} \mathrm{H}_{13} \mathrm{ClO}_{6}$ : C, 69.16; $\mathrm{H}, 2.79$.Found $\mathrm{C}, 69.20 ; \mathrm{H}, 2.75$.

\subsection{Synthesis of 4-[(4-Aminophenyl)amino]-2H-chromen-2-one (3)}

To a boiling solution of the 4-chloro coumarin $(10 \mathrm{~g}, 0.05 \mathrm{~mol})$ and little amount of Triethyl amine in ethanol (30 $\mathrm{mL}$ ) was added to a boiling solution of $p$-phenylene diamine $(6.09 \mathrm{~g}, 0.05 \mathrm{~mol})$ in ethanol $(30 \mathrm{~mL})$. The mixture was refluxed for $1 \mathrm{~h}$ and left at room temperature for $4-5 \mathrm{~h}$. The precipitate was separated and recrystallized from DMF. Yield:78 \%; m.p. 265-273 C; IR ( KBr, cm $\left.{ }^{-1}\right) 3341.78$ (NH str. for $\left.2^{0}\right), 3290.67$, $\left(\mathrm{NH} \mathrm{for} 1^{0}\right), 1664.62(\mathrm{C}=\mathrm{O}$ of coumarin); ${ }^{1} \mathrm{H}-\mathrm{NMR}\left(400 \mathrm{MHz}\right.$, DMSO- $\left.d_{6}\right) \delta 6.53-7.26(\mathrm{~m}, 7 \mathrm{H}, \mathrm{Ar}-\mathrm{H}), 3.31\left(\mathrm{~s}, 2 \mathrm{H}, \mathrm{NH}_{2}\right), 3.76(\mathrm{~s}, 1 \mathrm{H}, \mathrm{C}-\mathrm{NH})$, 7.93 (d, $1 \mathrm{H}, \mathrm{H}$ at C-5 of coumarin), 5.75 (s, $1 \mathrm{H}, \mathrm{H}$ at C-3 of coumarin); ${ }^{13} \mathrm{C}$ NMR 88.22, 116.51, 118.91, 121.80, 123.59, 124.25, 125.79, 131.84, 132.55, 145.13, 149.08, 155.32, 161.98. Anal. Calcd. For $\mathrm{C}_{15} \mathrm{H}_{12} \mathrm{~N}_{2} \mathrm{O}_{2}$ : C, 71.42 ; H, 4.79; N, 11.10. Found C, 71.40; H, 4.82; N, 11.06 .

\subsection{General procedure for the synthesis of Schiff bases (4a-i)}

To a solution of compound $3(1.36 \mathrm{~g} ; 0.01 \mathrm{~mol})$ in absolute ethanol $(50 \mathrm{~mL})$, containing a catalytic amount of piperidine, equimolecular amount of the appropriate aldehydes (for e.g. benzaldehyde) was added. The reaction mixture was heated under refluxed for 5-6 h. It was then cooled at room temperature, poured into crushed ice, filtered, washed, dried and recrystallized from DMF to yield 4-[(4-\{[(E)-phenylmethylidene]amino $\}$ phenyl)amino]-2H-chromen-2-one. Other Schiff bases were obtained in similar manner. 


\subsection{General procedure for the synthesis of spiro $\beta$-lactum derivatives (5a-i)}

A mixture of different Schiff bases (4a-i) $(0.002 \mathrm{~mol})$ and triethylamine (TEA) $(0.004 \mathrm{~mol})$ was dissolved in 1 , 4-dioxane $(50 \mathrm{~mL})$ and cooled and stirred. To this well stirred solution chloro acetyl chloride $(0.004 \mathrm{~mol})$ was added drop wise within a period of 20 minute. The reaction mixture was then stirred for further $3 \mathrm{~h}$ and then refluxed for $8 \mathrm{~h}$.The resultant mixture was concentrated, cooled, then poured into ice-cold water and then extracted with ethyl acetate. The solvent was evaporated and the product thus obtained was purified by column chromatography over silica gel using $15 \%$ ethyl acetate: $85 \%$ benzene as eluent. Recrystallisation from ether/n-hexane yields azetidinone derivatives (5a-i).

\subsubsection{Characterization data of synthesized compound}

3- Chloro-1-[4-(2-oxo-2H-chromen-4-ylamino)-phenyl\}-4-phenyl-azetidin-2-one(5a).

Yield: $73 \%$; m.p. $252-254^{\circ} \mathrm{C}$; IR $\left(\mathrm{KBr}, \mathrm{cm}^{-1}\right): 3296.46$ (N-H str.), $1718.63(\mathrm{C}=\mathrm{O}$ of $\beta$-lactum $), 1664.62(\mathrm{C}=\mathrm{O}$ of coumarin), 806.27(C-Cl bending); ${ }^{1} \mathrm{H}$-NMR (400 MHz, DMSO- $\left.d_{6}\right) \delta$ 6.55-7.68 (m,12H,Ar-H); 3.76 (s,1H,C-NH); 7.93 (d, 1H, H at C-5 of coumarin), 5.75 (s, 1H, H at C-3 of coumarin), 4.97 (d,1H, CH-Cl of azetidinone), 5.19 (d,1H, CH-Ar of azetidinone); ${ }^{13} \mathrm{C}$ NMR 55.67, 60.45, 88.22, 116.11, 117.50, 120.85, 123.59, $124.25,125.79,128.52,130.36,132.55,135.40,136.09,136.45,140.96,149.08,155.26,161.23,162.59$. Anal. Calcd. For $\mathrm{C}_{24} \mathrm{H}_{17} \mathrm{ClN}_{3} \mathrm{O}_{5}$ : C, 62.41; H, 3.49; N, 9.10. Found: $\mathrm{C}, 62.40 ; \mathrm{H}, 3.47 ; \mathrm{N}, 9.10$.

3-Chloro-4-(4-nitrophenyl)-1-\{4-[(2-oxo-2H-chromen-4-yl)amino]phenyl $\}$ azetidin-2-one(5b).

Yield: 68\%; m.p. 256-259 ${ }^{\circ} \mathrm{C}$; IR $\left(\mathrm{KBr}, \mathrm{cm}^{-1}\right)$ : 3296.46 (N-H str.), $1718.63(\mathrm{C}=\mathrm{O}$ of $\beta$-lactum), 1664.62 (C=O of coumarin), 823.63 (C-Cl bending), $1552.75 \mathrm{~cm}^{-1}\left(\mathrm{~N}=\mathrm{O}\right.$ str.); ${ }^{1} \mathrm{H}-\mathrm{NMR}\left(400 \mathrm{MHz}, \mathrm{DMSO}-d_{6}\right) \delta$ 6.53-7.70 $(\mathrm{m}, 11 \mathrm{H}, \mathrm{Ar}-\mathrm{H}) ; 3.76(\mathrm{~s}, 1 \mathrm{H}, \mathrm{C}-\mathrm{NH}) ; 7.93(\mathrm{~d}, 1 \mathrm{H}, \mathrm{H}$ at $\mathrm{C}-5$ of coumarin), $5.75(\mathrm{~s}, 1 \mathrm{H}, \mathrm{H}$ at $\mathrm{C}-3$ of coumarin), $4.97\left(\mathrm{~d}, 1 \mathrm{H}, \mathrm{CH}-\mathrm{Cl}\right.$ of azetidinone), $5.19\left(\mathrm{~d}, 1 \mathrm{H}, \mathrm{CH}-\mathrm{Ar}\right.$ of azetidinone); ${ }^{13} \mathrm{C}$ NMR 52.26, 85.38, 117.75, $123.11,123.40,124.04,124.32,125.79,126.16,128.45,130.19,132.99,137.74,142.09,148.37,152.84$, 153.93,159.26, 162.06. Anal. Calcd. For $\mathrm{C}_{24} \mathrm{H}_{17} \mathrm{ClN}_{3} \mathrm{O}_{5}: \mathrm{C}, 62.41 ; \mathrm{H}, 3.49 ; \mathrm{N}, 9.10$. Found: C, 62.40; H, 3.47; N, 9.10 .

3-Chloro-4-(3-nitrophenyl)-1-\{4-[(2-oxo-2H-chromen-4-yl)amino]phenyl $\}$ azetidin-2-one(5c).

Yield: $65 \%$; m.p. $273--275^{\circ} \mathrm{C}$; IR $\left(\mathrm{KBr}, \mathrm{cm}^{-1}\right): 3296.46$ (N-H str.), $1716.70(\mathrm{C}=\mathrm{O}$ of $\beta$-lactum $), 1664.62(\mathrm{C}=\mathrm{O}$ of coumarin), 833.28(C-Cl bending), $1536.35 \mathrm{~cm}^{-1}\left(\mathrm{~N}=\mathrm{O}\right.$ str.) ; ${ }^{1} \mathrm{H}-\mathrm{NMR}\left(400 \mathrm{MHz}\right.$, DMSO- $\left.d_{6}\right) \delta$ 6.55-7.69 $(\mathrm{m}, 11 \mathrm{H}, \mathrm{Ar}-\mathrm{H}) ; 3.76(\mathrm{~s}, 1 \mathrm{H}, \mathrm{C}-\mathrm{NH}) ; 7.93(\mathrm{~d}, 1 \mathrm{H}, \mathrm{H}$ at C-5 of coumarin), 5.75 (s, 1H, H at C-3 of coumarin), $4.97\left(\mathrm{~d}, 1 \mathrm{H}, \mathrm{CH}-\mathrm{Cl}\right.$ of azetidinone), 5.19(d,1H, CH-Ar of azetidinone); ${ }^{13} \mathrm{C}$ NMR 52.30, 85.38, 117.65, 123.11, 123.40,124.04, 124.38, 125.77, 126.10, 127.50, 130.15, 132.95, 136.08, 142.05, 147.49, 152.80, 153.97,159.20, 162.10. Anal. Calcd. For $\mathrm{C}_{24} \mathrm{H}_{17} \mathrm{ClN}_{3} \mathrm{O}_{5}$ : C, 62.41; H, 3.49; N, 9.10. Found: C, 62.40; H, 3.47; N, 9.10.

3-Chloro-4-(3,4-dimethoxy-phenyl)-1-[4-(2-oxo-2H-chromen-4-ylamino)-phenyl]-azetidin-2-one(5d). Yield: $70 \%$; m.p. $281-285^{\circ} \mathrm{C}$; IR $\left(\mathrm{KBr}, \mathrm{cm}^{-1}\right): 3296.46(\mathrm{~N}-\mathrm{H}$ str. $), 1716.70(\mathrm{C}=\mathrm{O}$ of $\beta$-lactum $), 1664.62(\mathrm{C}=\mathrm{O}$ of coumarin), 842.92 (C-Cl bending), $1286.56 \mathrm{~cm}^{-1}\left(\mathrm{Ar}_{-} \mathrm{OCH}_{3}\right) ;{ }^{1} \mathrm{H}-\mathrm{NMR}\left(400 \mathrm{MHz}, \mathrm{DMSO}-d_{6}\right) \delta 6.58-7.60$ (m,10H,Ar-H); $3.76(\mathrm{~s}, 1 \mathrm{H}, \mathrm{C}-\mathrm{NH}) ; 7.93(\mathrm{~d}, 1 \mathrm{H}, \mathrm{H}$ at C-5 of coumarin), $5.75(\mathrm{~s}, 1 \mathrm{H}, \mathrm{H}$ at C-3 of coumarin), 3.38 $\left(\mathrm{S}, 3 \mathrm{H},-\mathrm{OCH}_{3}\right), 4.97(\mathrm{~d}, 1 \mathrm{H}, \mathrm{CH}-\mathrm{Cl}$ of azetidinone $), 5.19(\mathrm{~d}, 1 \mathrm{H}, \mathrm{CH}-\mathrm{Ar}$ of azetidinone $) ;{ }^{13} \mathrm{C}$ NMR $55.96,56.15$, 85.38, 115.00, 117.55, 122.37, 123.30, 124.11, 126.36, 129.52,129.66, 136.20, 149.20, 149.70, 149.81, 152.81, 152.40, 153.89, 159.82, 160.72, 161.99. Anal. Calcd. For $\mathrm{C}_{26} \mathrm{H}_{21} \mathrm{ClN}_{2} \mathrm{O}_{5}$ : C, 65.48; H, 4.44; N, 5.87 Found: C, $65.47 ; \mathrm{H}, 4.45 ; \mathrm{N}, 5.85$.

3-Chloro-4-(4-chloro-phenyl)-1-[4-(2-oxo-2H-chromen-4-ylamino)-phenyl]-azetidin-2-one(5e).

Yield: $78 \%$; m.p. $270-272^{0} \mathrm{C}$; IR (KBR, $\left.\mathrm{cm}^{-1}\right): 3296.46$ (N-H str.), $1703.20(\mathrm{C}=\mathrm{O}$ of $\beta$-lactum), $1664.62(\mathrm{C}=\mathrm{O}$ of coumarin), 827.70 .70 (C-Cl bending), $751.30 \mathrm{~cm}^{-1}(\mathrm{Ar}-\mathrm{C}-\mathrm{Cl}) ;{ }^{1} \mathrm{H}$-NMR (400 MHz, DMSO- $\left.d_{6}\right) \delta$ 6.56-7.66 $(\mathrm{m}, 11 \mathrm{H}, \mathrm{Ar}-\mathrm{H}) ; 3.76(\mathrm{~s}, 1 \mathrm{H}, \mathrm{C}-\mathrm{NH}) ; 7.93(\mathrm{~d}, 1 \mathrm{H}, \mathrm{H}$ at C-5 of coumarin), 5.75 (s, 1H, H at C-3 of coumarin), 4.97(d,1H, CH-Cl of azetidinone), 5.19(d,1H, CH-Ar of azetidinone); ${ }^{13} \mathrm{C}$ NMR 60.45, 65.10, 85.30, 116.11, 117.50, 118.91, 120.85, 123.59, 124.25, 125.79, 129.08, 129.23, 131.84, 135.76, 136.09, 140.96, 149.08, 155.26, 161.23, 162.59. Anal. Calcd. For $\mathrm{C}_{24} \mathrm{H}_{16} \mathrm{Cl}_{2} \mathrm{~N}_{2} \mathrm{O}_{3}:$ C, 63.87; H, 3.57; N, 6.21. Found: C, 63.89; H, 3.55; N, 6.21.

3-Chloro-4-(4-methylphenyl)-1-\{4-[(2-oxo-2H-chromen-4-yl)amino]phenyl $\}$ azetidin-2-one(5f).

Yield: $72 \%$; m.p. $258-260^{\circ} \mathrm{C}$; IR $\left(\mathrm{KBr}, \mathrm{cm}^{-1}\right)$ : 3296.46 (N-H str.), 1700.31 (C=O of $\beta$-lactum), 1664.62 (C=O of coumarin), 821.70 (C-Cl bending), $1454.38 \mathrm{~cm}^{-1}\left(\mathrm{Ar}_{-} \mathrm{CH}_{3}\right) ;{ }^{1} \mathrm{H}$-NMR (400 MHz, DMSO- $\left.d_{6}\right) \delta$ 6.58-7.69 (m,11H,Ar-H), $3.76(\mathrm{~s}, 1 \mathrm{H}, \mathrm{C}-\mathrm{NH}), 7.93\left(\mathrm{~d}, 1 \mathrm{H}, \mathrm{H}\right.$ at C-5 of coumarin), $2.16\left(\mathrm{~S}, 3 \mathrm{H}, \mathrm{CH}_{3}\right), 4.97(\mathrm{~d}, 1 \mathrm{H}, \mathrm{J}=2.2 \mathrm{~Hz}$ CH-Cl of azetidinone), 5.19(d,1H, J=2.3 Hz CH-Ar of azetidinone); ${ }^{13} \mathrm{C}$ NMR 21.15, 59.45, 60.04, 85.35, 116.11, $117.50,118.91,120.85,123.59,124.25,125.79,129.49,130.44,132.19,133.25,136.09,140.96,149.08,155.26$, 
161.23, 162.26. Anal. Calcd. For $\mathrm{C}_{25} \mathrm{H}_{19} \mathrm{ClN}_{2} \mathrm{O}_{3}$ : C, 69.69; H, 4.44; N, 6.50. Found: C, 69.65; H, 4.42; N, 6.49.

2-(3-Chloro-4-oxo-1-\{4-[(2-oxo-2H-chromen-4-yl)amino]phenyl $\}$ azetidin-2-yl)benzaldehyde(5g).

Yield: $75 \%$; m.p. $289-291^{0} \mathrm{C}$; IR $\left(\mathrm{KBr}, \mathrm{cm}^{-1}\right)$ : 3296.46 (N-H str. ), 1716.47 (C=O of $\beta$-lactum), $1664.62(\mathrm{C}=\mathrm{O}$ of coumarin), 842.78 (C-Cl bending), 2951.19 (Ar-CHO Str); ${ }^{1} \mathrm{H}$-NMR (400 MHz, DMSO- $d_{6}$ ) $\delta \quad 6.55-7.66$ (m,11H,Ar-H), 3.76 (s,1H,C-NH), 7.93 (d, 1H, H at C-5 of coumarin), 5.75 (s, 1H, H at C-3 of coumarin), 10.22 (s,1H,CHO), 4.97(d,1H, CH-Cl of azetidinone), 5.19(d,1H, CH-Ar of azetidinone); ${ }^{13} \mathrm{C}$ NMR 55.40, 56.72, $86.45,116.11,117.50,118.91,120.85,123.59,124.25,125.79,128.56,133.43,134.71,135.07,135.41,136.09$, 140.96, 141.26, 149.08, 155.26, 161.23, 162.59, 191.59. Anal. Calcd. For $\mathrm{C}_{25} \mathrm{H}_{17} \mathrm{ClN}_{2} \mathrm{O}_{4}: \mathrm{C}, 67.50 ; \mathrm{H}, 3.85 ; \mathrm{N}$, 6.30. Found: C, 67.48; H, 3.84; N, 6.30 .

3-Chloro-4-naphthalen-1-yl-1-[4-(2-oxo-2H-chromen-4-ylamino)-phenyl]-azetidin-2-one(5h).

Yield: $68 \%$; m.p. $297-300^{\circ} \mathrm{C}$; IR (KBr,cm $\left.{ }^{-1}\right): 3296.46$ (N-H str.), 1691.63 (C=O of $\beta$-lactum), $1664.62(\mathrm{C}=\mathrm{O}$ of coumarin), 840.10 (C-Cl bending); ${ }^{1} \mathrm{H}-\mathrm{NMR}\left(400 \mathrm{MHz}\right.$, DMSO- $\left.d_{6}\right) \delta$ 6.53-7.90 (m,14H,Ar-H), 3.76 (s,1H,C-NH), 7.93 (d, 1H, H at C-5 of coumarin), 5.75 (s, 1H, H at C-3 of coumarin), 4.97(d,1H, CH-Cl of azetidinone), $5.19\left(\mathrm{~d}, 1 \mathrm{H}, \mathrm{CH}-\mathrm{Ar}\right.$ of azetidinone); ${ }^{13} \mathrm{C}$ NMR 54.48, 85.57, 116.11, 117.50, 118.91, 120.85, 123.59, $124.25,125.79,126.27,127.12,127.19,127.38,128.66,132.29,136.09,138.18,140.96,149.08,155.26,161.23$, 162.59. Anal. Calcd. For $\mathrm{C}_{28} \mathrm{H}_{19} \mathrm{ClN}_{2} \mathrm{O}_{3}$ : C, 72.03; H, 4.10; N, 6.00. Found: C, 72.02; H, 4.13; N, 6.02.

3-Chloro-4-(2-chloro-quinolin-3-yl)-1-[4-(2-oxo-2H-chromen-4-ylamino)-phenyl]-azetidin-2-one(5i).

Yield: 79\%; m.p. $289-292^{0} \mathrm{C}$; IR $\left(\mathrm{KBr}, \mathrm{cm}^{-1}\right)$ : 3296.46 (N-H str.), 1697.41 (C=O of $\beta$-lactum), $1664.62(\mathrm{C}=\mathrm{O}$ of coumarin), 823.63 (C-Cl bending), 753.23(Ar-C-Cl); ${ }^{1} \mathrm{H}-\mathrm{NMR}$ (400 MHz, DMSO- $\left.d_{6}\right) \delta 6.54-7.80$ (m,12H,Ar-H), $3.76(\mathrm{~s}, 1 \mathrm{H}, \mathrm{C}-\mathrm{NH}), 7.93$ (d, 1H, H at C-5 of coumarin), 5.75 (s, 1H, H at C-3 of coumarin), 4.97(d,1H, CH-Cl of azetidinone), $5.19\left(\mathrm{~d}, 1 \mathrm{H}, \mathrm{CH}-\mathrm{Ar}\right.$ of azetidinone); ${ }^{13} \mathrm{C}$ NMR 58.85, 68.30, 85.32, 116.11, 117.50, 118.91, 120.85 , $123.59,124.25,125.79,128.66,128.84,130.08,132.55,136.09,138.80,140.96,144.75,148.26,149.08,155.26$, 161.23,162.28. Anal. Calcd. For $\mathrm{C}_{27} \mathrm{H}_{17} \mathrm{Cl}_{2} \mathrm{~N}_{3} \mathrm{O}_{3}$ : C, 64.55; H, 3.41; N, 8.36. Found: C, 64.51; H, 3.40; N, 8.35.

\subsection{Antimicrobial activity}

All the synthesized compounds were tested for their antibacterial and antifungal activity (MIC-minimum inhibition concentration) in vitro by broth dilution method with two gram positive bacteria $S$. aureus and $B$. subtilis and gram negative bacteria E. coli, P. aeruginosa, and fungi species like C. albicans, A. niger organisms taking ciprofloxacin, ampicillin, chloramphenicol, norfloxacin, flucanazole, griseofulvin, and nystatin. Muller Hinton broth was used as nutrient medium to grow and dilute the drug suspension for test. DMSO was used as a diluent which not effected the growth of microbes.

\section{Results and Discussion}

All the reactions were carried out under conventional methods. 4-[(4-Aminophenyl)amino]-2H- chromen-2-one 3 was a key intermediate that required to prepare the target product. 4-Chloro coumarin 2 was prepared from 4-hydroxy coumarin 1 . The selectivity of the reaction of 1 with $\mathrm{POCl}_{3}$ was low, because a considerable amount of 4-chloro-3, 4', 3', 4"-tercoumarin was formed as a byproduct. In this method n-hexane was used to improve the yield of 4-chloro coumarin and significantly decreased yield of the by product. The key intermediate 4-[(4-aminophenyl)amino]-2H-chromen-2-one 3 was easily prepared from 4-chloro coumarin using little amount of triethyl amine. The IR spectra of compound 3 revealed a strong band at $3290.67 \mathrm{~cm}^{-1}$ confirming the presence of $2^{0}-\mathrm{NH}$ group and band at $3341.78 \mathrm{~cm}^{-1}$ indicating the presence of $1^{0}-\mathrm{NH}_{2}$ group. The IR spectrum of compound 3 showed a band at $1664.62 \mathrm{~cm}^{-1}$ which is the characteristic for $\mathrm{C}=\mathrm{O}$ of coumarin. The ${ }^{1} \mathrm{H}$ NMR of compound 3 showed signal between 6.53-7.26 $\delta \mathrm{ppm}$ for aromatic protons. Compound $4 \mathbf{b}$ showed a characteristic band at $3290 \mathrm{~cm}^{-1}$ observed for $2^{0}-\mathrm{NH}$ group which indicate the disappearance of $-\mathrm{NH}_{2}$ gr. of $\mathbf{3}$ and confirmed the formation of Schiff base. Stretching vibration for $\mathrm{C}=\mathrm{N}$ of Schiff base present at 1473-1602 $\mathrm{cm}^{-1}$. The ${ }^{1} \mathrm{H}$ NMR showed signal between 6.55-7.52 $\delta \mathrm{ppm}$ for aromatic protons. All the Schiff bases reacted with chloro acetyl chloride to afford azetidinone derivatives. Compound $\mathbf{5 b}$ showed a characteristic band at $1718.63 \mathrm{~cm}^{-1}$ confirming the presence of $\mathrm{C}=\mathrm{O}$ group and $\mathrm{C}-\mathrm{Cl}$ present at $831.35 \mathrm{~cm}^{-1}$ of azetidinone. The ${ }^{1} \mathrm{H}$ NMR of $\mathbf{5 b}$ showed signal between 6.53-7.70 for aromatic protons and doublet at 4.97 for $\mathrm{CHCl}$ of azetidinone. ${ }^{13} \mathrm{C}$ NMR of $\mathbf{5 b}$ showed characteristic peak at 52.26, 35.38, 117.75, 123.11, 123.40, 124.04, 124.32, 125.79, $126.16,128.45,130.19,132.99,137.74,142.09,148.37,152.84,153.93,159.26$, and 162.06. All the compound 5a-i was synthesized diastreroselectively. In compound $\mathbf{5 f} \mathrm{J}=2.2 \mathrm{~Hz}(\mathrm{CHCl}$ of azetidinone) and $\mathrm{J}=2.3 \mathrm{~Hz}(\mathrm{CH}-\mathrm{Ar}$ of azetidinone).

All the newly synthesized compounds were screened for their antimicrobial activity. Azetidinone derivatives with Ar gr. such as 4-chloro phenyl, 4-methy phenyl and 2-chloro quinonyl found to be more active than others. 
From the result in table 1 Schiff base $4 \mathbf{e}$ showed excellent activity when compared with ampicillin and chloramphenicol; while $\mathbf{5 a}, \mathbf{5 e}, \mathbf{5 f}$ and $\mathbf{5 i}$ demonstrated good activity against $E$.coli and $\mathbf{5 f}, \mathbf{5 i}$ significant activity against P.aeruginosa; while $\mathbf{4 c}, \mathbf{5 b}, \mathbf{5 e}, \mathbf{5 i}$ showed good activity against $S$.aureus and $\mathbf{5 g}$ and $\mathbf{5 i}$ demonstrated significant activity against $B$.subtilis when compared with standard drug ampicillin.

From the MIC results of fungal activity, Schiff base $\mathbf{4 d}$ was found equipotent to Nystatin; while $\mathbf{4 a}, \mathbf{4 c}, \mathbf{4 e}, \mathbf{4 f}, \mathbf{4 g}$, $\mathbf{4 h}, \mathbf{4 i}$ demonstrated significant activity. The azetedinones $\mathbf{5 c}, \mathbf{5 d}, \mathbf{5 e}, \mathbf{5 f}, \mathbf{5 g}, \mathbf{5 h}, \mathbf{5 i}$ demonstrated good activity against $C$. albicans when compared with Griseofulvin. All remaining compounds demonstrated good to moderate activity against remaining fungal specie (A. niger).

\section{Conclusion}

A series of coumarin based azetidine-2-one compounds were successfully synthesized and tested for their in vitro antimicrobial activity. Overall conclusion made for synthesized compounds are that most of the compounds were more active against E. coli, S. aureus and B. subtilis. Some of the compounds were found equipotent to ampicillin and chloramphenicol such as $\mathbf{5 e}, \mathbf{5 f}, \mathbf{5 i}$ and found less active than other standard drugs. Most of the compounds demonstrated antifungal activity for C. albicans similar to that of Griseofulvin and found less active than other fungal specie (A. niger).

\section{References}

Azizian, J., Mohammadi, A., Bidar, I., Mirazaei, P. (2008). $\mathrm{KAl}\left(\mathrm{SO}_{4}\right)_{2} .12 \mathrm{H}_{2} \mathrm{O}$ (alum) a reusable catalyst for the synthesis of some 4- substituted coumarins via pechmann reaction under solvent-free condition. Montash Chem, 139:805.

Deklc, S.V., Deklc, V.S., Deklc, B.R., Deklc, M.S. (2007). Synthesis of new condensed and cyclised coumarin derivatives. Chem.Pap., 61(3):233.

El-Saghier, A.M., Khodairry, A. (2000). New synthetic approaches to condensed and spiro coumarins: coumarin-3- thiocarboxamide as building block for the synthesis of condensed and spiro coumarins. Phosphorou, Sulfur and Silicon, 160:105.

Garazd, M.M., Muzychka, O.V., Vovk, A.I., Nagorichna, I.V., Ogorodniichuk, A.S. (2007). Modified coumarins.27. Synthesis and Antioxidant activity of 3-substituted 5, 7- dihydroxy-4- methyl coumarins. Chemistry of Natural Compounds, 43(1):19.

Hamdi, N., Lidrissi, C., Saoud, M., Nievas, A.R., Zarrouk, H. (2006). Synthesis of some new biologically active coumarin derivatives. Chemistry of Heterocyclic Compounds, 42(3): 2006.

Kotali, A., Lafazanis, I., Harris, P. (2008). Synthesis of 6, 7,-diacylcoumarins via the transformation of a hydroxyl into a carbonyl group. Synthetic communications, 38: 3996.

Kováč, M., Sabatié, A., Floch, L. (2001). Synthesis of coumarin sulfonamides and sulfonylurea. Arkivoc, 6:100-108.

Kumar, V., Jayadevalah, K.V., Nagaraja, T.S., Bharathi, D.R., Shameer, H., Jayachandaran, E., Sreenivasa G.M. (2009). Synthesis, characterization and antimicrobial activity of new N-substituted -3-chloro-2-azetidinones. Arch Pharma Sci \& Res, 1(1):31.

Lee, S., Sivakumar, K., Seobshin, W., Xie, F., Wang, Q. (2006). Synthesis and anti angiogenesis activity of coumarin derivatives. Bioorganic \& Medicinal Chemistry Letters, 16:4596.

Maheswara, M., siddaiah, V., Damu, G.L., Rao, Y.K., Rao, C.V. (2006). A solvent free synthesis of coumarins via pechmann condensation using heterogeneous catalyst. Journal of molecular catalysis A: Chemical., 255: 49.

Moghadam, K., Mohseni, M. (2004). A route to the synthesis of novel coumarins. Montash Chem, 135:817.

Musicki, B., Periers, A.M., Laurin, P., Ferroud, D., Benedetti, Y., Lachaud, S., Chatreaux, F., Haesslein, J.L., lltis, A., Pierre, C., Khider, J., Tessot, N., Airault, P., Bonnefoy, A., Vicat, P., Klich, M. (2000). Improved antibacterial activity of Ru 79115. Bioorg. Med. Chem. Lett., 10:1695-1699.

Rajasekaran, A., Periasamy, M., Venkatesan, S. (2010). Synthesis, characterization and biological activity of some novel azetedinones. Journal of Developmental Biology and Tissue Engineering, 2(1):5-6.

Rajitha, B., Naveen, V., Someshwar, P., Madhav, J., Narsimha, P., Thirupathi, Y. (2006). Dipyridine copper chloride catalyzed coumarin synthesis via pechmann condensation under conventional heating and microwave irradiation. Arkivoc, 12: 23. 
Satyanarayan, V.S., Sreevani, P., Sivakumar, A. (2008). Synthesis and antimicrobial activity of new Schiff bases containing coumarin moiety and their spectral characterization. Arkivoc, 17:221.

Sharma, M.C., Sahu, N.K., Kohli, D.V., Chaturvedi, S.C., Sharma, S. (2009). Synthesis, characterization and biological activities of some 1-(Nicotinylamino)-2 substituted azetidine-4-ones as potential antibacterial agents. Digest Journal of Nanomaterial And Biostructures, 4:361.

Sizova, Z.A., Karasev, A.A., Lukatskaya, L.L., Rubtsov, M.I., Doroshenko A.O. (2002). Acid-base properties of 3- benzolyl coumarins and their imino analogs. Theoretical and experimental Chemistry, 38 (3): 2002.

Smitha, G.., Sanjeeva, R. (2004). $\mathrm{ZrCl}_{4}$ - catalysed pechmann reaction: synthesis of coumarins under solvent free condition. Synthetic communications, 34(21):3998.

Toraskar, M., Kulkarni, V., Kadam, V. (2010). Azetidinone: A bio active moiety. Journal of Pharmacy Research, 3(1): 169-173.

Zabradnik, M. (1992). The production and application of fluorescent brightening agents. John wiley \& Sons, New York.

Zuo, H., Jose, G., Boli, Z., Hyunmoon, B., Soo Shin, D., Ghate, M. (2008). Microwave- assisted synthesis of fluorinated coumarino sulfonamides. Arkivoc, 2:183.

Table 1. Antimicrobial study (MIC $\mu \mathrm{g} / \mathrm{mL}$ ) of synthesized compound 4a-5i. Minimum inhibitory concentration

\begin{tabular}{|l|l|l|l|l|l|l|l|}
\hline $\begin{array}{l}\text { Comp. } \\
\text { no. }\end{array}$ & Ar & \multicolumn{2}{l}{ Gram negative } & \multicolumn{2}{l|}{ Gram positive } & \multicolumn{2}{l|}{$\begin{array}{l}\text { Fungal } \\
\text { species }\end{array}$} \\
\hline & & $\begin{array}{l}\text { E. } \\
\text { coli }\end{array}$ & $\begin{array}{l}\text { aeruginosa } \\
\text { and }\end{array}$ & $\begin{array}{l}\text { aureus } \\
\text { andilis }\end{array}$ & $\begin{array}{l}\text { B. } \\
\text { albicans }\end{array}$ & $\begin{array}{l}\text { A. } \\
\text { niger }\end{array}$ \\
\hline 4a & Phenyl & 500 & 1000 & 500 & 1000 & 500 & 1000 \\
\hline 4b & 4-Nitro phenyl & 200 & 200 & 500 & 1000 & 800 & 1000 \\
\hline 4c & 3-Nitro phenyl & 500 & 200 & 100 & 200 & 500 & 1000 \\
\hline 4d & 3,4-dimethoxy phenyl & 200 & 500 & 1000 & 200 & 100 & 500 \\
\hline 4e & 4-chloro phenyl & 50 & 100 & 200 & 100 & 500 & $>1000$ \\
\hline 4f & 4-methyl phenyl & 100 & 200 & 1000 & 500 & 200 & 500 \\
\hline 4g & Phenyl-2-carboxaldehyde & 500 & 1000 & 800 & 100 & 500 & 1000 \\
\hline 4h & Naphthyl & 500 & 250 & 800 & 100 & 400 & 1000 \\
\hline 4i & 2-chloro quinonyl & 250 & 400 & 500 & 100 & 400 & $>1000$ \\
\hline 5a & Phenyl & 200 & 200 & 250 & 500 & 1000 & 1000 \\
\hline 5b & 4-Nitro phenyl & 500 & 250 & 200 & 100 & 1000 & 500 \\
\hline 5c & 3-Nitro phenyl & 250 & 500 & 1000 & 200 & 500 & $>1000$ \\
\hline 5d & 3,4-dimethoxy phenyl & 500 & 1000 & 1000 & 400 & 200 & 500 \\
\hline 5e & 4-chloro phenyl & 50 & 200 & 200 & 200 & 400 & 500 \\
\hline 5f & 4-methyl phenyl & 100 & 150 & 500 & 200 & 100 & 1000 \\
\hline 5g & Phenyl-2-carboxaldehyde & 200 & 200 & 500 & 50 & 200 & $>1000$ \\
\hline 5h & Naphthyl & 500 & 1000 & 250 & 100 & 200 & 500 \\
\hline 5i & 2-chloro quinonyl & 100 & 150 & 200 & 50 & 200 & 500 \\
\hline Ampicillin & 100 & 100 & 250 & 100 & - & - \\
\hline ciprofloxacin & 25 & 25 & 50 & 50 & - & - \\
\hline chloramphenicol & 50 & 50 & 50 & 50 & - & - \\
\hline Norfloxacin & 10 & 10 & 10 & 10 & - & - \\
\hline Griseofulvin & & & & & 500 & 100 \\
\hline Nystatin & & & & & 100 & 100 \\
\hline Flucanazole & & & & 10 & 10 \\
\hline
\end{tabular}




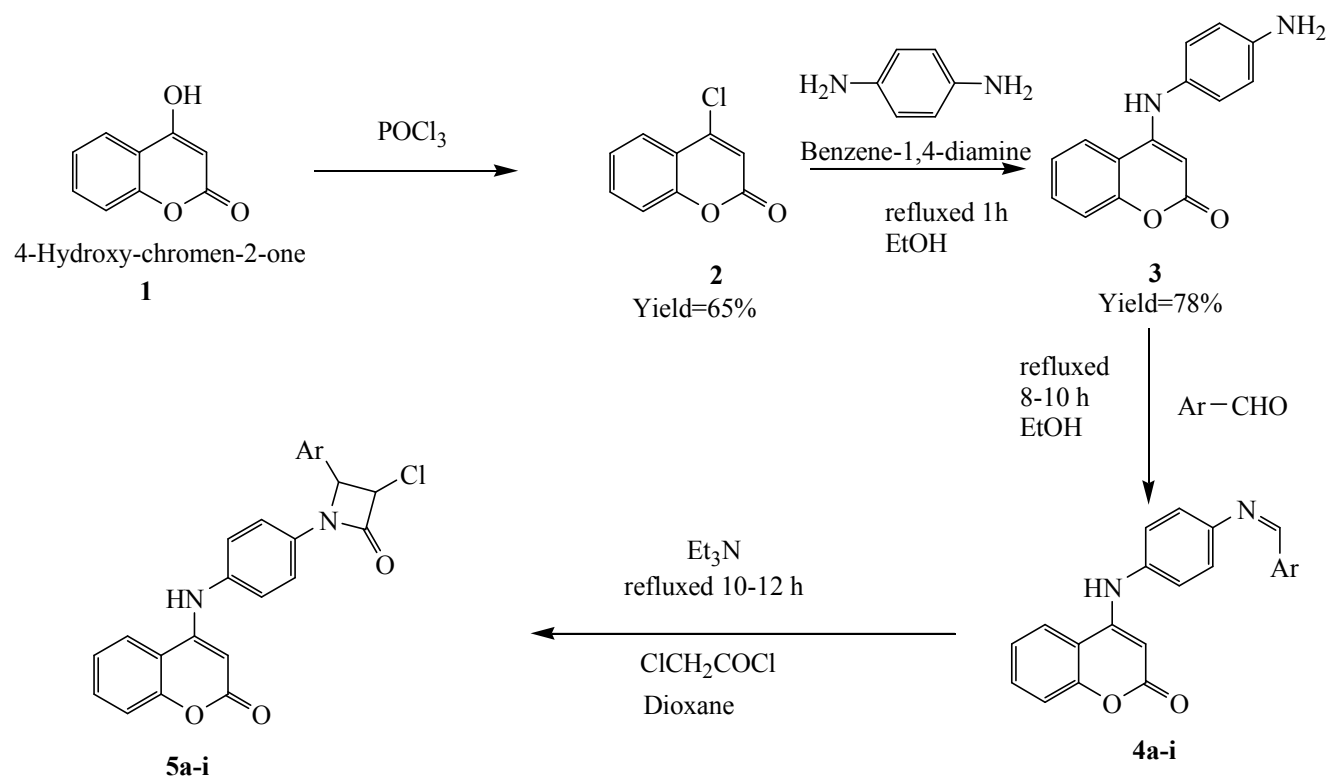

Scheme: Synthesis of azetidine -2-ones derivatives

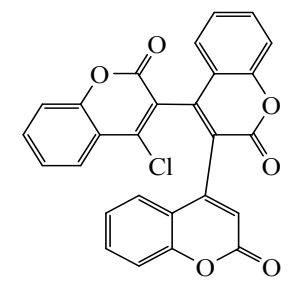

4-Chloro-3, 4',3',4"-tercoumarin 2a

Yield $=17 \%$

\begin{tabular}{|c|l|}
\hline & Ar \\
\hline a & Phenyl \\
\hline b & 4-Nitro phenyl \\
\hline c & 3-Nitro phenyl \\
\hline$d$ & 3,4-dimethoxy phenyl \\
\hline e & 4-chloro phenyl \\
\hline $\mathrm{f}$ & 4-methyl phenyl \\
\hline g & Phenyl-2-carboxaldehyde \\
\hline h & Naphthyl \\
\hline i & 2-chloro quinonyl \\
\hline
\end{tabular}

